7. Reprod. Fert. (1968) 15, 295-304

\title{
CONCEPTION AND PARTURITION OF MICE AT TWO TEMPERATURES
}

\author{
S. A. BARNETT AND M. J. LITTLE \\ Department of Zoology, Glasgow University, Scotland
}

(Received 10th Fuly 1967)

Summary. Mice of strains $\mathrm{A} / \mathrm{Tb}, \mathrm{A} 2 \mathrm{G} / \mathrm{Tb}, \mathrm{C} 57 \mathrm{BL} / \mathrm{Tb}$, the $\mathrm{F}_{1}$ generation from the last two, and a genetically mixed stock have been bred in permanently mated pairs. One colony of each type was in a room kept at $21^{\circ} \mathrm{C}$, another at $-3^{\circ} \mathrm{C}$. The dates of birth of their litters, and the number of young born and weaned (at 3 weeks), were recorded. Information on 2708 intervals between parturitions has been analysed.

The distribution of intervals was always bimodal. The first mode, which represented conceptions at post-partum oestrus, was at 20 or 21 days, at both temperatures, with the following exceptions: at $21^{\circ} \mathrm{C}$, the C57BL mice had a mode at $24 / 25$ days after lost litters, and at 26 days after surviving litters; at $-3^{\circ} \mathrm{C}$, the $\mathrm{A} 2 \mathrm{G}$ mice had a mode of 31 days, and the G57BL of 28 days, both after surviving litters. Evidently, the C57BL mice were particularly subject to lactation delay. After postpartum conception, delayed birth, due to lactation, was proportional to the number of young weaned in the previous litter, except in strain $\mathrm{A}$ at $21^{\circ} \mathrm{C}$. The influence of lactation was greater at $-3^{\circ} \mathrm{C}$ than at $21^{\circ} \mathrm{C}$ in all three inbred strains and also in the mixed stock, when the effect was measured by the percentage of intervals of less than 25 days. But in terms of modal intervals between parturitions only strains $A$ and $A 2 G$ displayed an effect of temperature. There was no evidence that the cold environment lengthened gestation in the absence of sucklings.

Second modes, representing post-lactation conceptions, were at 45 to 50 days. The proportion of post-lactation conceptions (about $25 \%$ in inbred strains at $21^{\circ} \mathrm{C}$ ) was higher at $-3^{\circ} \mathrm{C}$, but only when the previous litter survived. At $21^{\circ} \mathrm{C}$ percentages of post-lactation conceptions were higher among the $\mathrm{F}_{1}$ and mixed stocks than among inbreds. Dispersions about both modes were greater at $-3^{\circ} \mathrm{C}$ than at $21^{\circ} \mathrm{C}$.

It is suggested that the supply of foodstuffs for anabolism was a crucial influence in determining the interval between parturitions at $-3^{\circ} \mathrm{C}$.

\section{INTRODUCTION}

Mice, Mus musculus, breeding in rooms kept at $-3^{\circ} \mathrm{C}$, have been compared, in previous work, with controls at $21^{\circ} \mathrm{C}$. The age at which the vagina opens and the first oestrus are later in the cold; the oestrous cycles may be longer; and the age of first parturition is later (Barnett \& Goleman, 1959, 1960). For one strain 
(A2G) at least, the age at which reproduction ceases is later in the cold environment (Barnett, 1962). The number of litters produced in a given time is lower in the cold (Barnett, 1961, 1962). The accumulated information from about 12 years of this work now allows an analysis of the effect of cold on the distribution of intervals between parturitions, and hence some inferences on the times of effective conceptions, and the influence of lactation on pregnancy, in two environments.

\section{MICE AND METHODS}

The mice were of three inbred strains, $\mathrm{A} 2 \mathrm{G} / \mathrm{Tb}, \mathrm{A} / \mathrm{Tb}$ and $\mathrm{C} 57 \mathrm{BL} / \mathrm{Tb}$, and a mixed stock obtained by crossing these three and one other, GFF. (In the account which follows, the substrain symbol, Tb, is omitted.) Some observations were also made on $F_{1}$ mice derived from matings between strains $A 2 G$ and C57BL. These are called ' $F_{1}$ ' in the tables. Table 1 summarizes the material used. All the mice belonged to colonies breeding permanently in rooms kept at one of two temperatures, namely, $21^{\circ} \mathrm{C}$ (controls) and $-3^{\circ} \mathrm{C}$. The inbred

TABLE 1

SUMMARY OF MATERIAL

\begin{tabular}{|c|c|c|c|c|c|c|c|}
\hline \multirow{2}{*}{$\begin{array}{c}\text { Class of } \\
\text { mice }\end{array}$} & \multirow{2}{*}{$\begin{array}{c}\text { Temperature } \\
\qquad\left({ }^{\circ} \mathrm{C}\right)\end{array}$} & \multirow{2}{*}{$\begin{array}{l}\text { No. of } \\
\text { pairs }\end{array}$} & \multirow[t]{2}{*}{ Generations } & \multicolumn{2}{|c|}{$\begin{array}{l}\text { No. of intervals } \\
\text { after litters }\end{array}$} & \multicolumn{2}{|c|}{$\begin{array}{c}\text { Age at first } \\
\text { parturition (days) }\end{array}$} \\
\hline & & & & Surviving & Lost & Mean & Range \\
\hline $\mathrm{A} / \mathrm{Tb}$ & $\begin{array}{r}21 \\
-3\end{array}$ & $\begin{array}{r}102 \\
96\end{array}$ & $\begin{array}{r}17 \text { to } 31 \\
1 \text { to } 12\end{array}$ & $\begin{array}{l}326 \\
127\end{array}$ & $\begin{array}{l}26 \\
29\end{array}$ & $\begin{array}{l}72 \cdot 4 \\
88 \cdot 3\end{array}$ & $\begin{array}{l}55-120 \\
58-148\end{array}$ \\
\hline $\mathrm{A} 2 \mathrm{G} / \mathrm{Tb}$ & $\begin{array}{r}21 \\
-3\end{array}$ & $\begin{array}{r}188 \\
66\end{array}$ & $\begin{array}{c}1 \text { to } 23,30 \text { to } 37 \\
6 \text { to } 13\end{array}$ & $\begin{array}{l}628 \\
108\end{array}$ & $\begin{array}{r}137 \\
10\end{array}$ & $\begin{array}{l}69 \cdot 5 \\
97 \cdot 4\end{array}$ & $\begin{array}{l}53-107 \\
55-158\end{array}$ \\
\hline $\mathrm{C} 57 \mathrm{BL} / \mathrm{Tb}$ & $\begin{array}{r}21 \\
-3\end{array}$ & $\begin{array}{l}199 \\
124\end{array}$ & $\begin{array}{l}3 \text { to } 34 \\
2 \text { to } 21\end{array}$ & $\begin{array}{l}609 \\
214\end{array}$ & $\begin{array}{l}47 \\
39\end{array}$ & $\begin{array}{l}74 \cdot 8 \\
89 \cdot 7\end{array}$ & $\begin{array}{l}53-151 \\
55-154\end{array}$ \\
\hline $\mathrm{F}_{1}^{*}$ & $\begin{array}{r}21 \\
-3\end{array}$ & $\begin{array}{l}10 \\
18\end{array}$ & - & $\begin{array}{l}37 \\
47\end{array}$ & $\begin{array}{l}0 \\
0\end{array}$ & $\begin{array}{l}59 \cdot 7 \\
74 \cdot 3\end{array}$ & $\begin{array}{l}56-68 \\
62-122\end{array}$ \\
\hline Mixed & $\begin{array}{r}21 \\
-3\end{array}$ & $\begin{array}{l}76 \\
84\end{array}$ & $\begin{array}{c}6,9 \text { to } 13,20 \\
3 \text { to } 6,12,14,20,22\end{array}$ & $\begin{array}{l}167 \\
120\end{array}$ & $\begin{array}{l}18 \\
19\end{array}$ & $\begin{array}{l}72 \cdot 2 \\
83 \cdot 3\end{array}$ & $\begin{array}{l}51-87 \\
63-138\end{array}$ \\
\hline
\end{tabular}

* $\mathrm{C} 57 \mathrm{BL} \times \mathrm{A} 2 \mathrm{G}$ and reciprocal cross.

and $F_{1}$ mice were in permanent brother-sister pairs from the age of 5 weeks. The mixed stock was outcrossed at the age of 5 to 8 weeks. The birth of litters was recorded daily, at about 10.00 hours; hence the time of birth was accurate to 24 hours. The number of young in each litter was recorded at birth, and on weaning at 21 days. Pairs were usually killed at the age of 28 weeks, or later if they had an unweaned litter at that age. A few were kept to the end of their breeding period; observations on these have been analysed separately. Some analyses are based on smaller numbers than the totals given in Table 1; these numbers are given in the relevant tables.

Diet 41 (Bruce \& Parkes, 1949) and water were provided in excess; at $-3^{\circ} \mathrm{C}$ the water was either in open jars or in the form of blocks of ice which the mice licked. Further information on methods is given elsewhere (Barnett, 1956; Barnett \& Manly, 1959). 


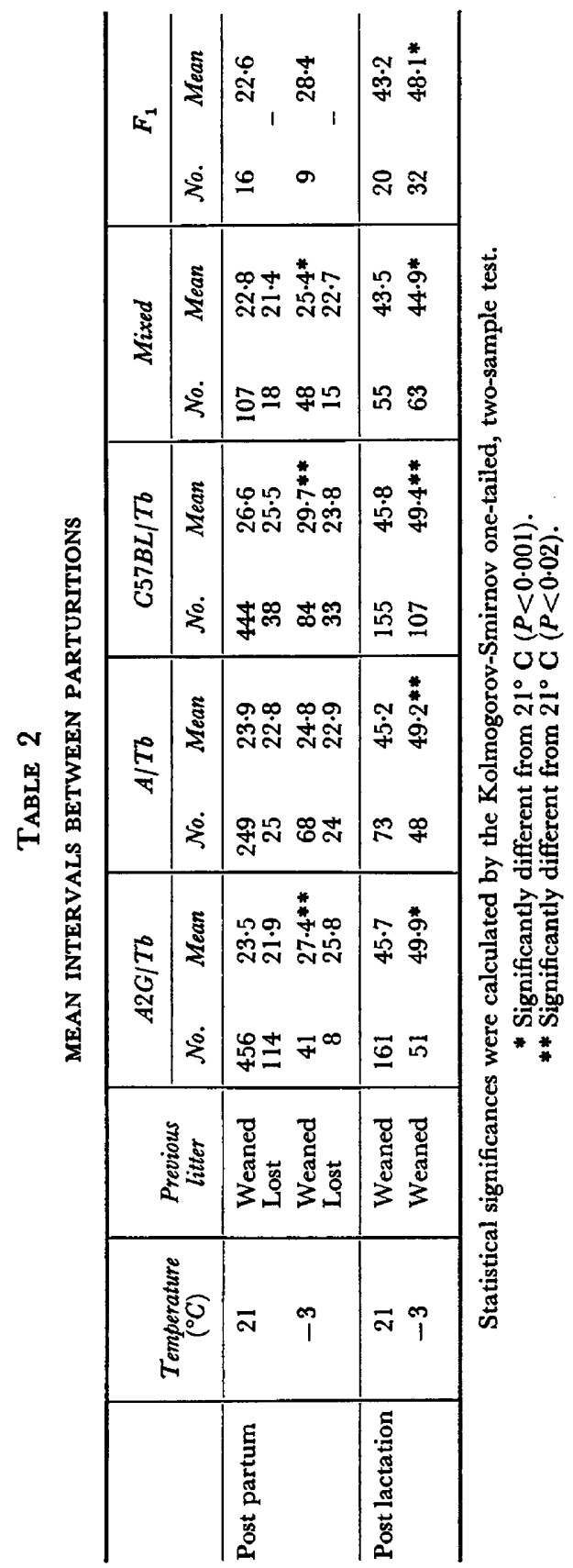


Age at first parturition

\section{RESULTS}

Table 1 gives figures on ages at first parturition. The distributions were very skewed, as the ranges show. Most pairs had their first litter within 40 days of mating, but in all groups, except the $F_{1}$ and mixed stocks at $21^{\circ} \mathrm{C}$, some females went beyond 100 days before giving birth. Table 1 shows also: (i) there were differences among the inbred strains; (ii) the mixed stock was quicker to conceive than any inbred strain; and (iii) low environmental temperature led to longer delay before parturition in each class.

\section{Bimodality of parturition intervals}

Text-figure 1 gives the distributions of parturition intervals, after weaned litters only, for all classes. Each is bimodal. The mean intervals associated with each mode are given in Table 2. The first mode for all classes except three was at 21 days (Table 4). The A2G mice at $-3^{\circ} \mathrm{G}$ had a mode at 31 days; the G57BL mice had a mode at 26 days at $21^{\circ} \mathrm{C}$, and 28 days at $-3^{\circ} \mathrm{C}$. The distribution about these atypical modes was nearly symmetrical, unlike those of the other classes of mice. The second modes were at 45 to 50 days; the distributions about them were fairly symmetrical, but the second modes were less clearly defined than the first.

Each first mode represents conceptions at post-partum oestrus; the second, at post-lactation oestrus. The latter very rarely occurs until 12 or 13 days post partum (Bruce \& East, 1956). If the uncomplicated gestation of $M$. musculus is taken as about 20 days, all parturition intervals of 33 days or less represent post-partum conceptions; of these, intervals of 21 to 33 days represent varying delays of implantation due to lactation (Lataste, 1887; Kirkham, 1916; Mirskaia \& Crewe, 1931; Enzmann, Saphir \& Pincus, 1932; Brambell, 1937; Bruce \& East, 1956). The very few intervals of 34 to 37 days are difficult to evaluate: they may represent unusually delayed post-partum conceptions (Enzmann et al., 1932), or unusually early post-lactation conceptions. In the analysis that follows we have taken all intervals below 37 days as representing post-partum conceptions; this allows for a maximum consisting of 20 days gestation, plus 16 days delayed implantation, plus recording error of 1 day.

\section{Effects of temperature}

The cold environment left the distributions bimodal, but increased the dispersion around each (Text-fig. 1). The first modes of the mixed stock and of strain A remained at 21 days in the cold; that of $A 2 G$ was at 31 days, and of C57BL at 28 instead of 26 days.

In the cold the second mode of all strains except $A$ was one or more days further to the right than in the warm. This was perhaps due to a longer lactation at $-3^{\circ} \mathrm{C}$ and a later occurrence of post-lactation oestrus.

Table 3 gives the percentages of successful implantations associated with the first mode. Since the mice were discarded 23 weeks after mating, the pairs which had shorter intervals between parturitions, and therefore more intervals in the time during which they were bred, are excessively represented in the distributions. Hence all first modes are probably more marked than they would be if this effect were allowed for. 
Nevertheless, Table 3 shows the following: (i) At $21^{\circ} \mathrm{C}$ most conceptions were post-partum; only the $F_{1}$ mice were exceptions. (ii) At both temperatures the proportion of successful post-partum conceptions was higher when the

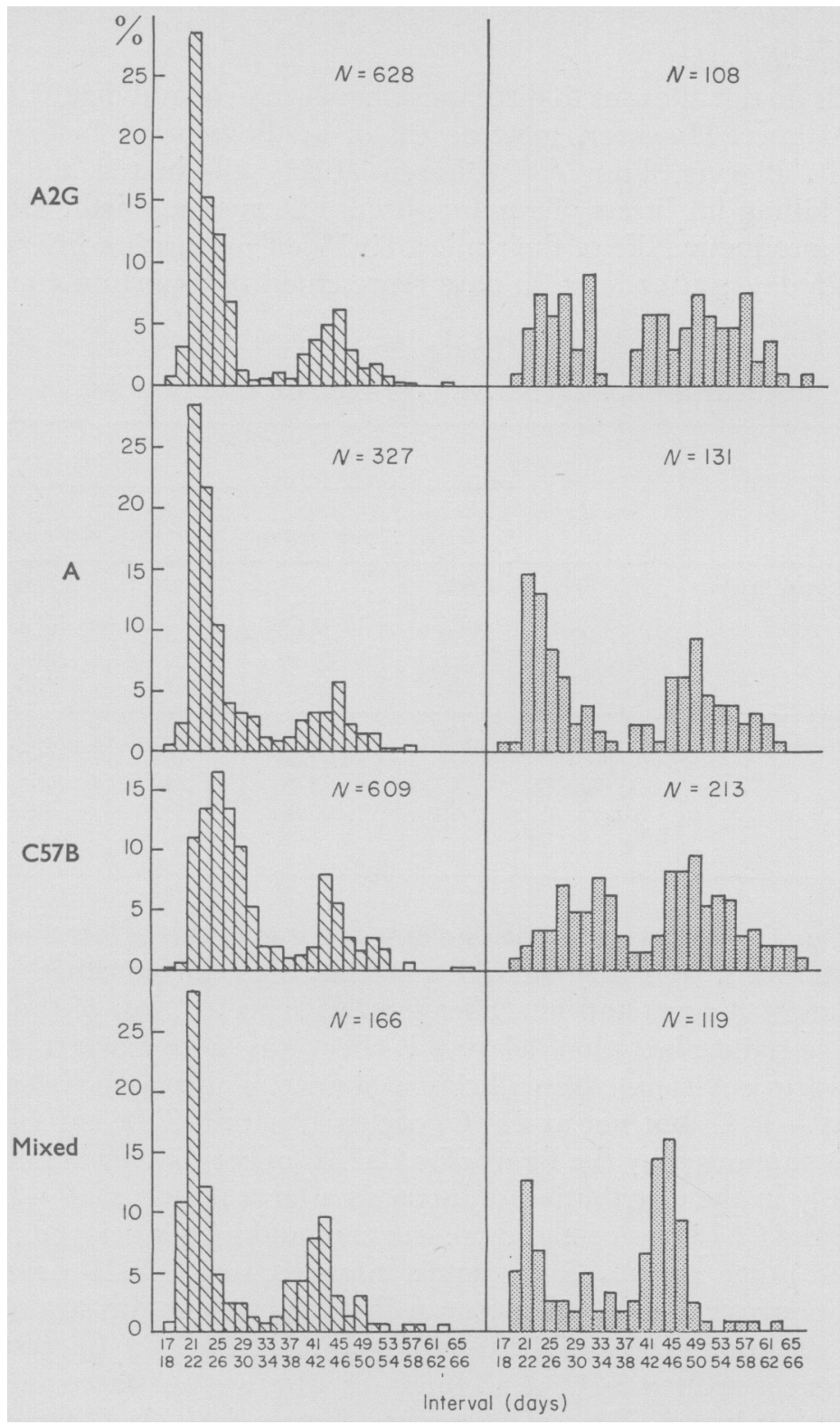

Text-Fig. 1. The distributions of interval lengths between parturitions, after weaned litters only, at $21^{\circ} \mathrm{C}$ (left-hand graphs) and $-3^{\circ} \mathrm{C}$ (right-hand graphs) for four strains of mice.

previous litter was totally lost. (iii) The proportion of successful post-partum conceptions after weaned litters was much lower at $-3^{\circ} \mathrm{C}$ than at $21^{\circ} \mathrm{C}$. Nevertheless, the first modes after lost litters (Table 4) were usually close to 
those after weaned litters: they were at 21 days for A2G and the mixed stock at both temperatures; and at 20 days for A at both temperatures. Strain C57BL was atypical and is considered further below.

\section{Variation in lactation delay}

Our records do not allow us to distinguish between neonatal deaths and those that occurred later. However, most deaths of nestlings occur before 10 days (unpublished). Biggers, Finn \& McLaren (1961) eliminated the effect of lactation by killing all litters of random-bred TO mice at birth. During the first half of reproductive life of their mice, $83.5 \%$ of parturition intervals were of less than 25 days; a mode at 20 days represented post-partum conceptions.

TABLE 3

PERCENTAGES OF EFFECTIVE POST-PARTUM CONCEPTIONS

\begin{tabular}{|c|c|c|c|c|c|}
\hline & \multirow[b]{2}{*}{$\begin{array}{l}\text { Strain of } \\
\text { mice }\end{array}$} & \multicolumn{2}{|c|}{$21^{\circ} C$} & \multicolumn{2}{|c|}{$-3^{\circ} \mathrm{C}$} \\
\hline & & $\begin{array}{l}\text { No. of } \\
\text { intervals }\end{array}$ & $\begin{array}{c}\% \\
\text { post partum }\end{array}$ & $\begin{array}{l}\text { No. of } \\
\text { intervals }\end{array}$ & $\begin{array}{c}\% \\
\text { post partum }\end{array}$ \\
\hline After weaned litters & $\begin{array}{l}\mathrm{A} 2 \mathrm{G} / \mathrm{Tb} \\
\mathrm{A} / \mathrm{Tb} \\
\mathrm{C} 57 \mathrm{BL} / \mathrm{Tb} \\
\text { Mixed } \\
\mathrm{F}_{1}\end{array}$ & $\begin{array}{r}628 \\
327 \\
609 \\
166 \\
36\end{array}$ & $\begin{array}{l}73 \cdot 5 \\
76 \cdot 0 \\
75 \cdot 9 \\
64 \cdot 2 \\
44 \cdot 4\end{array}$ & $\begin{array}{r}108 \\
131 \\
213 \\
119 \\
41\end{array}$ & $\begin{array}{l}37 \cdot 0 \\
52 \cdot 1 \\
39 \cdot 2 \\
39 \cdot 4 \\
22 \cdot 0\end{array}$ \\
\hline After lost litters & $\begin{array}{l}\text { A2G/Tb } \\
\text { A/Tb } \\
\text { C57BL/Tb } \\
\text { Mixed } \\
\text { F }_{1}\end{array}$ & $\begin{array}{r}138 \\
26 \\
47 \\
18 \\
-\end{array}$ & $\begin{array}{c}83 \cdot 0 \\
92 \cdot 3 \\
83 \cdot 2 \\
100 \cdot 0 \\
-\end{array}$ & $\begin{array}{l}10 \\
29 \\
39 \\
19 \\
-\end{array}$ & $\begin{array}{c}80 \cdot 0 \\
93 \cdot 2 \\
84 \cdot 4 \\
78 \cdot 8 \\
-\end{array}$ \\
\hline
\end{tabular}

Accordingly, in Table 4, we give the percentages of intervals of less than 25 days after (a) lost litters, and (b) surviving litters. Our mixed stock at $21^{\circ} \mathrm{C}$ resembled that of Biggers and his colleagues. As expected, loss of the previous litter tended to reduce lactation delay; this effect was more marked in the cold than in the warm environment in all classes of mice. This may be because most total losses at $-3^{\circ} \mathrm{C}$, but not at $21^{\circ} \mathrm{C}$, occurred within 3 days of birth. This supposition is supported by the figures for C57BL mice: this strain had a mode of 21 days only in the distribution of intervals after total losses at $-3^{\circ} \mathrm{C}$.

Evidently, the C57BL mice had more frequent and longer delayed implantation than the other strains. Since some intervals were of 21 days or less, post-partum oestrus can evidently occur at the usual time in this strain, and uncomplicated gestation can be of the usual length. At $21^{\circ} \mathrm{C}$ C57BL gestations of 21 days or less constituted $5.2 \%$ of all intervals after weaned litters, and $12.4 \%$ of those after lost litters. The corresponding figures for $-3^{\circ} \mathrm{C}$ were 6.0 and $35.9 \%$. The first modes after weaned litters, of 26 days and 28 days, respectively, in the two temperatures, show that the modal lactation delay was 5 days in the warm and 7 days in the cold. The C57BL mice at $21^{\circ} \mathrm{C}$, therefore, resembled the Swiss mice described by Mantalenakis \& Ketchel (1966): their mean gestation after mating was about 24 days. The distribution about the second 
mode of the C57BL mice in the cold suggests that many conceptions took place 30 to 36 days after the birth of the previous litter.

The peculiar pattern of the C57BL mice was not displayed by the $\mathrm{F}_{1}$ hybrids of that strain with A2G. At $21^{\circ} \mathrm{C}$ their distribution of intervals resembled that of the A2G mice, with a mode of 21 days.

TABLE 4

EFFECT OF LACTATION AFTER POST-PARTUM CONGEPTION

\begin{tabular}{l|c|c|c|c|c}
\hline & & \multicolumn{2}{|c|}{ After lost litters } & \multicolumn{2}{|c}{ After surviving litters } \\
\cline { 2 - 5 } & $\begin{array}{c}\text { Temperature } \\
\left({ }^{\circ} C\right)\end{array}$ & $\begin{array}{c}\text { Modal } \\
\text { interval } \\
(\text { days })\end{array}$ & $\begin{array}{c}\text { Intervals of } \\
<25 \text { days } \\
(\%)\end{array}$ & $\begin{array}{c}\text { Modal } \\
\text { interval } \\
(\text { days })\end{array}$ & $\begin{array}{c}\text { Intervals of } \\
<25 \text { days } \\
(\%)\end{array}$ \\
\hline A2G/Tb & 21 & 21 & $71 \cdot 4$ & 21 & $50 \cdot 0$ \\
& -3 & 21 & $62 \cdot 5$ & 31 & $34 \cdot 1$ \\
A/Tb & 21 & 20 & $60 \cdot 7$ & 21 & $53 \cdot 2$ \\
& -3 & 20 & $51 \cdot 5$ & 21 & $29 \cdot 1$ \\
C57BL/Tb & 21 & 24 to 25 & $29 \cdot 7$ & 26 & $25 \cdot 2$ \\
Mixed & -3 & 21 & $56 \cdot 5$ & 28 & $6 \cdot 1$ \\
& 21 & 21 & $83 \cdot 0$ & 21 & $54 \cdot 7$ \\
& -3 & 21 & $67 \cdot 8$ & 21 & $24 \cdot 2$ \\
\hline
\end{tabular}

Numbers of intervals in each class as in Table 1.

The long lactation delay of the C57BL mice might be attributed partly to the fact that this strain has larger litters than the other two inbred strains (Barnett \& Manly, 1959; Barnett, 1961, 1964). Yet the mixed stock, which had a first mode at 21 days, had larger litters still. Accordingly, we examined the relationship between lactation delay and the number of young weaned, by

TABLE 5

REGRESSIONS OF PARTURITION INTERVALS ON SIZE OF PREVIOUS LITTER AT 3 WEEKS: POST-PARTUM CONCEPTIONS

\begin{tabular}{|c|c|c|c|c|c|c|c|}
\hline \multirow{2}{*}{$\begin{array}{c}\text { Class } \\
\text { of } \\
\text { mice }\end{array}$} & \multirow{2}{*}{$\begin{array}{c}\text { Temperature } \\
\left({ }^{\circ} \mathrm{C}\right)\end{array}$} & \multirow{2}{*}{$\begin{array}{c}\text { No. } \\
\text { of } \\
\text { intervals }\end{array}$} & \multicolumn{2}{|c|}{ No. in litter } & \multirow{2}{*}{$\begin{array}{c}\text { Mean } \\
\text { interval } \\
\text { (days) }\end{array}$} & \multirow{2}{*}{$\begin{array}{l}\text { Regression } \\
\text { coefficient }\end{array}$} & \multirow{2}{*}{$P<$} \\
\hline & & & Mean & Range & & & \\
\hline $\mathrm{A} 2 \mathrm{G} / \mathrm{Tb}$ & $\begin{array}{r}21 \\
-3\end{array}$ & $\begin{array}{c}242^{*} \\
40\end{array}$ & $\begin{array}{l}5 \cdot 1 \\
4 \cdot 0\end{array}$ & $\begin{array}{l}1 \text { to } 11 \\
1 \text { to } 7\end{array}$ & $\begin{array}{l}23 \cdot 2 \\
26 \cdot 7\end{array}$ & $\begin{array}{l}+0.56 \\
+1.47\end{array}$ & $\begin{array}{l}0.001 \\
0.001\end{array}$ \\
\hline $\mathrm{A} / \mathrm{Tb}$ & $\begin{array}{r}21 \\
-3\end{array}$ & $\begin{array}{l}75^{*} \\
65\end{array}$ & $\begin{array}{l}5 \cdot 2 \\
4 \cdot 5\end{array}$ & $\begin{array}{l}2 \text { to } 11 \\
1 \text { to } 10\end{array}$ & $\begin{array}{l}24 \cdot 7 \\
24 \cdot 6\end{array}$ & $\begin{array}{l}-0.04 \\
+0.61\end{array}$ & $\overline{0.01}$ \\
\hline $\mathrm{C} 57 \mathrm{BL} / \mathrm{Tb}$ & $\begin{array}{r}21 \\
-3\end{array}$ & $\begin{array}{l}75^{*} \\
75^{*}\end{array}$ & $\begin{array}{l}6 \cdot 9 \\
4 \cdot 3\end{array}$ & $\begin{array}{l}2 \text { to } 10 \\
1 \text { to } 11\end{array}$ & $\begin{array}{l}27 \cdot 8 \\
29 \cdot 4\end{array}$ & $\begin{array}{l}+0.86 \\
+0.67\end{array}$ & $\begin{array}{l}0.001 \\
0.01\end{array}$ \\
\hline Mixed & $\begin{array}{r}21 \\
-3\end{array}$ & $\begin{array}{l}96 \\
38\end{array}$ & $\begin{array}{l}7 \cdot 7 \\
5 \cdot 7\end{array}$ & $\begin{array}{l}2 \text { to } 14 \\
1 \text { to } 10\end{array}$ & $\begin{array}{l}22 \cdot 9 \\
25 \cdot 8\end{array}$ & $\begin{array}{l}+0.63 \\
+1.02\end{array}$ & $\begin{array}{l}0.001 \\
0.01\end{array}$ \\
\hline
\end{tabular}

* Samples of the material available.

calculating the regressions of parturition interval on size of the previous litter at 3 weeks (Table 5). After post-partum conception, strain A showed no effect at $21^{\circ} \mathrm{C}$, but all the remaining regressions were highly significant. The regression coefficients in Table 5 give the increases in intervals between parturitions, in days, per weanling. In this respect, if in no other, the C57BL mice resembled 
other strains. The only significant regression after post-lactation conceptions was given by the mixed stock at $-3^{\circ} \mathrm{C}(P<0 \cdot 001)$. It is surprising that there was even one significant regression when conceptions were at post-lactation oestrus. Perhaps the larger litters of this strain matured more slowly and sucked longer, and so postponed post-lactation oestrus. Alternatively, there may have been lactation delay due to restoration of the milk flow after conception.

\section{Influence of age and parity}

Most of our observations are unsuitable as evidence on the effects of age or parity, since they refer only to about the first half of reproductive life. Later parturition intervals were on average shorter than earlier ones, but this is probably because only the females which had short intervals produced fifth, sixth or (rarely) seventh litters at $21^{\circ} \mathrm{C}$, or fourth and fifth at $-3^{\circ} \mathrm{C}$. This is supported by observations on twenty A2G pairs which were bred at $21^{\circ} \mathrm{C}$ to the end of reproductive life. Their mean interval lengths in days follow:

$\begin{array}{lclcccc}\text { First } & \text { Second } & \text { Third } & \text { Fourth } & \text { Fifth } & \text { Sixth } & \text { Seventh } \\ 30 \cdot 1 & 34.4 & 27 \cdot 7 & 26.4 & 33 \cdot 8 & 29 \cdot 2 & 29 \cdot 8\end{array}$

There is no evidence here of a decline in interval length with parity (cf. Biggers, Finn \& McLaren, 1962).

\section{DISCUSSION}

Our observations give some evidence on the influence on gestation of (a) genotype, (b) concurrent lactation, and (c) low environmental temperature. The effects of genotype and a cold environment, on reproduction in general, have been reviewed elsewhere (Barnett, 1965).

Our records were not designed to give an estimate of the length of gestation, but, when conception is at post-partum oestrus, the interval between parturitions gives the gestation period over-estimated by about $18 \mathrm{hr}$ (Runner \& Ladman, 1950; Biggers, Curnow, Finn \& McLaren, 1963). One question is whether our observations allow any conclusions on the length of gestation uncomplicated by concurrent lactation. Since the females were permanently mated, most pregnancies were prolonged by the presence of sucklings. When the previous litter was totally lost, the parturition interval tended to be less than after a surviving litter, but there was still usually some lactation delay (Table 4). The effect of losing a litter, in reducing lactation delay, was more marked at $-3^{\circ} \mathrm{C}$ than at $21^{\circ} \mathrm{C}$. This was perhaps because at $-3^{\circ} \mathrm{C}$ most total losses were during the first 3 days after birth, while at $21^{\circ} \mathrm{C}$ they were often later. Probably, the best estimates of the length of uncomplicated gestation are those given by the modes at $-3^{\circ} \mathrm{C}$ after lost litters. Since these were intervals between parturitions, they must over-estimate gestation by about 1 day. On this basis, even at $-3^{\circ} \mathrm{C}$, uncomplicated gestation took 19 or 20 days, and so there is no evidence that gestation was prolonged by the cold in the absence of lactation.

If 19 or 20 days represents the uncomplicated gestation of all strains at both temperatures (cf. Grüneberg, 1952), the effect of lactation is clearly shown in Text-fig. 1. At $21^{\circ} \mathrm{C}$ it was most marked among the $\mathrm{C} 57 \mathrm{BL}$ mice. At $-3^{\circ} \mathrm{C}$ it 
caused a flattening of the distribution curve, and a shift to the right, in all strains. Consequently, the C57BL pattern at $-3^{\circ} \mathrm{C}$ differed less from those of the other strains.

Our observations suggest that lactation delay in $M$. musculus is usually proportional to the number of sucklings present. All the regressions, except one, were highly significant (Table 5), even though they were on number in litter at 3 weeks and could not allow for deaths of some litter members between birth and weaning. The one anomaly was the absence of a regression in strain $\mathrm{A}$ at $21^{\circ} \mathrm{C}$. Such genetically determined aberrations may account for contradictory results in the literature.

Not all conceptions were post-partum, and the percentages of effective postpartum conceptions again showed the influences of genotype, lactation and temperature (Table 3). At $21^{\circ} \mathrm{G}$, in the three inbred strains, post-partum conceptions were successful on about $75 \%$ of occasions on which the previous litter was weaned. The mixed stock had a lower percentage, and the $\mathbf{F}_{1}$ lower still; these mice are more fertile than the inbreds (Barnett \& Coleman, 1960; Barnett, 1961); hence high fertility, measured by output of young, was in these instances correlated with rather high incidence of post-lactation conceptions. When a litter was lost at $21^{\circ} \mathrm{C}$, the probability of a successful post-partum conception was increased. At $-3^{\circ} \mathrm{C}$ the proportion of successful post-partum conceptions was much lower than at $21^{\circ} \mathrm{C}$, but only when the previous litter was weaned. The low figures at the top of the right hand column of Table 3 reflect the combined effects of cold and the presence of a viable litter. The figures indicate that these two factors, acting together, not only delayed implantation, but often either prevented it, or caused loss of early implanted embryos (cf. McCarthy, 1965). A less likely hypothesis is that there was often no post-partum oestrus when a viable litter was present.

It would be conventional to try to explain our observations on both lactation delay and the failure of post-partum conceptions at $-3^{\circ} \mathrm{C}$ by endocrine changes. But Barnett \& Little (1965) have brought evidence that the reproductive performance of $\mathrm{A} 2 \mathrm{G}$ female mice at $-3^{\circ} \mathrm{G}$ is limited by the amount of food they can eat; and Barnett \& Coleman (1959) have suggested that the reproductive cycle of female mice at $-3^{\circ} \mathrm{C}$ resembles that of mice on a low plane of nutrition. It is, therefore, at least plausible that the crucial factor is the supply of metabolites from food.

\section{ACKNOWLEDGMENTS}

We are grateful to the Nuffield Foundation, the Wellcome Foundation, the Royal Society and the Medical Research Council for generous grants in aid of this research.

\section{REFERENCES}

BARNETT, S. A. (1956) Endothermy and ectothermy in mice at $-3^{\circ}$ C. F. exp. Biol. 33, 124.

BARNETT, S. A. (1961) Some effects of breeding mice for many generations in a cold environment. Proc. R. Soc. B, 155, 115.

Barnett, S. A. (1962) Total breeding capacity of mice at two temperatures. F. Reprod. Fert. 4, 327.

BARNETT, S. A. (1964) Heterozygosis and the survival of young mice in two temperatures. Q. $\mathcal{J l}$ exp. Physiol. 49, 290. 
BARnett, S. A. (1965) Adaptation of mice to cold. Biol. Rev. 40, 5.

Barnetr, S. A. \& Coleman, E. M. (1959) The effect of low environmental temperature on the reproductive cycle of female mice. F. Endocr. 19, 232.

Barnetr, S. A. \& Coleman, E. M. (1960) 'Heterosis' in $\mathrm{F}_{1}$ mice in a cold environment. Genet. Res. 1, 25.

BARNetT, S. A. \& LitTLE, M. J. (1965) Maternal performance in mice at $-3^{\circ} \mathrm{G}$ : food consumption and fertility. Proc. R. Soc. B, 162, 492.

BarnetT, S. A. \& MANLy, B. M. (1959) Effects of low environmental temperature on the breeding performance of mice. Proc. R. Soc. B, 151, 87.

Biggers, J. D., Curnow, R. N., Finn, C. A. \& McLaren, A. (1963) Regulation of the gestation period in mice. F. Reprod. Fert. 6, 125.

Biggers, J. D., Finn, C. A. \& McLaren, A. (1961) Regulation of total reproductive output in the female mouse. Proc. IVth int. Congr. Anim. Reprod., The Hague.

Brggers, J. D., Frn, C. A. \& MCLAREN, A. (1962) Long-term reproductive performance of female mice. II. Variation of litter size with parity. F. Reprod. Fert. 3, 313 .

Brambell, F. W. R. (1937) The influence of lactation on the implantation of the mammalian embryo. Am. 7. Obstet. Gynec. 33, 942.

BRUGe, H. M. \& EAST, J. (1956) Number and viability of young from pregnancies concurrent with lactation in the mouse. F. Endocr. 14, 19.

Bruce, H. M. \& Parkes, A. S. (1949) Feeding and breeding of laboratory animals. 9. A complete cubed diet for mice and rats. F. Hyg., Camb. 47, 202.

Enzmann, E. V., Saphir, N. R. \& Pincus, G. (1932) Delayed pregnancy in mice. Anat. Rec. 54, 325.

GRÜNEBERG, H. (1952) The genetics of the mouse. Nijhoff, The Hague.

KIRKhaM, W. B. (1916) The prolonged gestation period in suckling mice. Anat. Rec. 11, 31.

LATASTE, F. (1887) Recherches de zooéthique sur les mammifères de l'ordre des rongeurs. Durand, Bordeaux.

Mantalenakis, S. J. \& Ketchel, M. M. (1966) Frequency and extent of delayed implantation in lactating rats and mice. 7 . Reprod. Fert. 12, 391.

MCCARTHY, J. C. (1965) Effects of concurrent lactation on litter size and prenatal mortality in an inbred strain of mice. 7 . Reprod. Fert. 9, 29.

Mirskaia, L. \& Crew, F. A. E. (1931) The pregnancy rate in the lactating mouse and the effect of suckling on the duration of pregnancy. Proc. $R$. Soc. Edinb. 51, 1.

Runner, M. N. \& Ladman, A. J. (1950) Time of ovulation and its diurnal regulation in the mouse. Anat. Rec. 108, 343. 